\title{
Learning and the Rhizome:
}

Reconceptualisation in the

Qualitative Research Process

\begin{abstract}
This article explores the concept of learning as a space of exchange and connection between signs, events and bodies, inspired by Gilles Deleuze's philosophy of difference. This qualitative methodology is based on the rhizome, with, amongst others, its characteristics or principles of heterogeneity, multiplicity and a-signification. It allows a productive conversation with studies of learning environments and sense productions through images and sounds from cinema media, such as the swimmer and swimming. The focus of this article is on learning, its environment and its role in the relationship between mind and world, pointing to an alternative to the representational perspective.
\end{abstract}

\section{Keywords}

Learning; qualitative analysis; knowledge; philosophy education; rhizome; representationalism
Find this article in http://magisinvestigacioneducacion.javeriana.edu.co/

doi: 10.11144/Javeriana.m11-22.Irrq

Antonio Carlos Rodrigues de Amorim acamorim@unicamp.br University of Campinas, School of Education, Brazil http://orcid.org/0000-0002-0323-9207

DAVID SCOTT

d.scott@ucl.ac.uk University College London, Institute of Education, United Kingdom http://orcid.org/0000-0002-4597-7566

\section{Resumen}

Este artículo explora el concepto de aprendizaje como espacio de intercambio y conexión entre signos, acontecimientos y cuerpos inspirado por la filosofía de la diferencia de Gilles Deleuze. Esta metodología cualitativa se basa en el Rizoma con sus características o principios de heterogeneidad, multiplicidad y a-significación, entre otras cosas. Permite una conversación productiva con estudios de entornos de aprendizaje y de producción de sentido a través de imágenes y sonidos provenientes de medios cinematográficos, tales como el del nadador y la natación. Este artículo se enfoca en el aprendizaje, su entorno y su papel en la relación entre mente y mundo, apuntando a una alternativa a la perspectiva representacional.

\section{Palabras clave}

Aprendizaje; análisis cualitativo; conocimiento; educación en filosofía; rizoma; representacionalísmo

To cite this article / Para citar este artículo

Rodrigues de Amorim, A. C. \& Scott, D. (2018). Learning and the Rhizome: Reconceptualisation in the Qualitative Research Process. magis, Revista Internacional de Investigación en Educación, 11 (22), 125-136. doi: 10.11144/Javeriana.m11-22.Irrq 
Article description | Descripción del artículo

This theoretical paper derived from the project Beyond Representation: Connections between Education and Experimental Video and Cinema Studies (2015/25656-1) is in the main theoretical and consists of a reflective and philosophical discussion about the idea of learning as a space of exchange and connection between knowledge, the senses, encounters and values, inspired by some of Gilles Deleuze and Félix Guattari's concepts. This allows us to create a nonrepresentionalist perspective as to how we can understand the key relationship between mind and world. The Rhizome is one of the principal ways we can contextualise notions of learning and difference through qualitative research.

\section{Introduction}

In this article we will pursue a particular line of argument, which, however difficult it is to follow, is essential to understanding a non-representationalist perspective on the mind-world relation and perhaps more importantly on how we can conduct qualitative research and determine what it is. In the first instance we need to distinguish this approach from what some have called a naive realist approach to educational and social research, which claims that knowledge of objects (i.e. entities in the world) reflects, corresponds to, or represents, the ontological state (cf. Scott, 2011, for a critical account of this approach). Thus our contention is that we cannot ignore philosophical questions such as what is the relationship between the knowledge we produce about the world and the world itself, since answering this question is a perquisite for doing any research at all.

Knowledge cannot be as a consequence treated unproblematically, as it is by many politicians who separate out facts from values in an unreflective way, or by journalists who refuse to accept that their carefully managed accounts of events and happenings in the world are always ideologically framed both in relation to their content and to how they are presented, or of course by many academics, not least in the field of education in which we work, whose brand of knowledge is both dangerously reductive and philosophically naïve. So, for example, some argue that the knowledge frame for any claim in the world and therefore for its truth criterion has to be reduced to concepts and the relations between them that can subsequently be measured; or that it is not possible to judge between different and rival theories about the same social object; or even that problems that come up during the course of a research project are technical in nature and not philosophical.

The argument we will be making here rests on four axioms: i) empirical research by necessity has an element of conceptual investigation; ii) an example of an important concept in the world, indeed one we use all the time in our empirical and theoretical investigations, is learning; iii) this involves an exploration of the relationship between mind and world; and iv) this exploration of the relationship can be understood as rhizomatic. We will take each of these in turn and address the issues that arise from them, and perhaps more importantly the relations between them. This is not an easy task but since the world itself is complicated it ill behoves us, as most qualitative and certainly most quantitative researchers do, to adopt reductionist and inadequately theorised approaches to research, and consequently to understanding the world.

\section{The Necessity of Conceptual Investigation}

Roy Bhaskar (1998) in his meta-theory of critical realism argues that researching the world can be understood as a series of action-sets. The first of these entails a process of identifying causal relationships as expressions of the tendencies of natural and social objects. The second of these is working out the components of a concrete event as it occurs in a particular context. The third is re-describing these components in theoretically significant ways. The fourth is a retroductive move or moving from describing the components of an event to proposing explanations about what produces or are the conditions for the event. The fifth is eliminating alternative possible explanations. The sixth is identifying adequate explanations. The seventh is correcting these proposed explanations in the light of the analysis that has just been conducted. And finally there is a need to 
explain these subsequent explanations and how they relate to the ontology and epistemology of the world.

The third of these action-steps is perhaps the most important. A concept is always embedded in a framework of other concepts. Traditional and reductionist forms of research separate out the concept from the framework, in order for it to have the properties of a variable. Having de-theorised the concept, relations are then identified between these different variables, even if the variable itself does not enter into a meaningful relationship with the world. So, for example, learning as a concept is positioned in a complicated network of other terms, such as innateness, trait theory, genetics, phenotypicality, habituation, classical conditioning, biology, enculturation, historical origin, evolutionary theory and many more, and if we are to use this concept in the world then we have to give due consideration to this network of other ideas. This points to the need to properly theorise the concepts and the relations between them that we use in our empirical investigations.

\section{Learning as a Concept}

As a concept, learning is fundamentally related to knowledge, and therefore if we are thinking about learning and the practices of learning, we also need to make reference to what is to be and how it is learned, and typically what we are aiming at in such considerations is some form of knowledge. Philosophers usually divide knowledge into two categories, knowing-that and knowing-how. (They sometimes add a third category, knowing-by-acquaintance, but this is not central to the argument that we are making.) The suggestion here is that these forms of knowledge are fundamentally different; in other words, there are strong and impermeable boundaries between them. We want to suggest using a formulation from Robert Brandom (2000) that this is misleading, and that consequently some of the problems that these strong insulations have created can be resolved. This has implications for the qualitative theory of learning and knowledge-development that we are arguing for here. We also want to suggest that in society these different forms of knowledge are given different statuses or have different attachments of importance, so, for example, vocational knowledge (broadly thought of as being about processes) is considered to be less important than academic knowledge (broadly understood as being about propositions), but these ascriptions of importance do not lie in the intrinsic nature of each knowledge form but in the way these knowledge forms are realized in particular societies.

Knowledge then, is fundamental to the three types of learning that can be identified: cognitive (relating to propositions), skill-based (relating to processes) and dispositional (relating to embodiments). Cognition comprises the manipulation of those symbolic resources (words, numbers, pictures etc.), which points to (though not necessarily in a mirroring or isomorphic sense) something outside itself, though the referent might also be construed as internally-related, or more specifically, as a part of an already established network of concepts (for example, cf. Brandom, 2000) or as expressive (for example, cf. Taylor, 1985). Skill-based knowledge is different from cognition because it is procedural and not propositional. Dispositional knowledge refers to relatively stable habits of mind and body, sensitivities to occasion and participation repertoires. Distinguishing between knowledge of how to do something (or process forms of knowledge), knowledge of something (or, in Brandom's terms, judging that claim in terms of its relations within and to a network of concepts, and making 
the subsequent commitments that this entails) and embodied forms of knowledge (assimilating an action and being able to perform in the spaces associated with that action) is important; however, they are in essence all knowledge-making activities, and furthermore as we will see can be formulated generically as acts of learning.

Robert Brandom (2000) suggests that acting in the world requires the use of, and is underpinned by, conceptual frameworks of one type or another. For him, propositional knowledge or making a claim that this or that is the case is, in common with the other two forms of knowledge, a process of doing and thus of knowing how to do something or other. And this results in all three types of knowledge having the same general form, and this allows them, in this form, to be understood as learning actions or acts of learning. As a result propositional knowledge-development activities are construed as individual processes that involve assertings, claimings, judgings and believings.

This means that propositional knowledge is not thought of as fundamentally different from procedural and embodied forms of knowledge since assertings, claimings, judgings and believings are of the same order as riding(s) (a horse, for example), driving(s) (a car, for example), teaching(s) (a class, for example) or cooking(s) (a meal, for example). Note the way these four activities are typically thought of as knowing-how processes, whereas the first four activities are usually thought of as knowing-that processes. However, what we are suggesting is that in order to make a claim of knowing, we are not, as commonly thought, providing a description of an experience (i.e. constructing propositional knowledge) but making a claim about it in what Wilfrid Sellars (1997) has described as 'a space of reasons', and that what follows from this is that we can and should understand and use concepts specifically in relation to current and future-oriented networks of meanings. Brandom (1994, p. 48) has described this as 'playing a role in the inferential game of making claims and giving and asking for reasons', with the notion of giving a reason being understood as the making of an inference, so that if one makes a claim of knowledge, the contents of that claim consist of inferential commitments made in applying it in the world and further to this, these commitments refer to both the circumstances surrounding its content and its consequences.

\section{Relations between Mind and World}

This strong version of inferentialism has been criticised on three counts: the translation of representational contents into inferential contents in every case cannot be satisfactorily made (Fodor \& Lepore, 2007); there is an over-emphasis on concept development and use and as a consequence an under-emphasis on other forms of knowledge development (Standish, 2016); and there is an implied conflation between inferences drawn from knowledge claims and inferences which are a central part of these claims or judgments.

And further to this, the issue of representationalism needs to be addressed. Both Robert Brandom and Charles Taylor reject crude versions of representationalism that have dominated previous and current theories of learning (and ways of understanding relations between mind and world), such as behaviourism and cognitivism. Representationalist theories of mind identify an inner realm of representations and an outer realm of objects in the world, which are placed in some form of dynamic tension. What follows from this and what should then be the focus of our investigation is not so much the existence of these two realms and the possibility 
of their identification, but the relationship between the two. The question then becomes, how do we understand the relationship between mind and world? Taylor (1985) argues that this relationship is one of action rather than representation (whether this is understood as correspondence, reflection, sameness or manifestation) and this formed the central concern of his expressivist philosophy. Brandom (2004, p. 2) also sought to heal 'the dualistic wound inflicted by the heedless use of an over-sharp distinction between mind and world'.

Both Taylor and Brandom in arguing for an expressivist view of the mind-world relation do so by prioritising expression before representation in the semantic process, that is, in the determination of meaning. (There are some important differences in their solutions to the problem, but they at least agree about the nature of the problem.) Expressing a feeling in action, for example, makes a difference to what that feeling is like. The minded action is not a representation of an action in the world, but, as Charles Taylor (2011, p. 23) suggests, 'an expression makes something manifest in an embodiment'. Moral judgements bring about something. They do not simply act as reflectors of some pre-formulated reality. Expression is a form of human activity. If meanings do not come before expression, then it is the expression itself that constitutes the meaning, though there are of course normative constraints on language-use and it is this that allows judgements to be made.

One manifestation of expressionism is the rhizome. Gregg Lambert (2012) suggests that this relationship finds its best expression in cinema and painting and also in the literature of Marcel Proust. These, for example, can point to new images of the other in the world. It is this that Gilles Deleuze wants to capture in philosophy, and in doing so he merges the difference of consciousness with the universe it manifests.

The point is to compose 'realities' (letters, words, literature) that are so fascinating that they overcome representation as the field of possibilities in a future, a 'how it could be'. That what is possible is created by the event and not its format. Images, sounds and words are affected by the event and can be thought of as vertiginous, somnambulistic, or even dream-like: a plane of composition and experimentation, as Bruce Baugh (2010, p. 94) suggests:

We experiment when we do not know what the result will be and have no preconceptions concerning what it should be. As an open-ended process that explores what's new and what's coming into being rather than something already experienced and known.

What sense data expresses is the experimentation of the event itself as a frontier that runs between propositions and things, statements and bodies, as the extra-being that first expresses that relation, a relation that does not exist outside the genesis of expression. It is an expression of many abstract entities in the world, including arts, education, politics and science.

\section{The Rhizome}

A rhizome has neither a beginning nor an end. Its shoots spring from the middle and grow horizontally in no predetermined way (cf. Masny, 2016). A rhizome maps its lines, a map that is produced and constructed, detachable, connectable, reversible, and modifiable. It has multiple entries and exits and it connects one point to another. The connections are 
heterogeneous. In analysing learning through rhizoanalytic pathways, we should consider it as a learning process with a set of pedagogic relations, that is, it incorporates a relationship between a learner and a learning object, which could be a person, a text, an object in nature, a particular array of resources, an artefact, an allocation of a role or function to a person, or a sensory object. A change process is required for this, and it is either internal to the learner or external to the community of which this learner is a member. The rhizome can also be comprehended as any network of things brought into contact with another, and it therefore functions as an assemblage, so that it can produce new effects, new ideas, and even new bodies (cf. Colman, 2010).

Instead of reinforcing the phenomenological in theorising about learning, we will suggest a decentring of the privileging of gaze or vision, and adopt a notion of aesthetics in which knowledge is produced through all kinds of embodied encounters with/in the world. This allows consideration of the conditions for learning, that is, the arrangement of resources, including spatial and temporal elements. These arrangements are embodied, discursive, institutional or agential, and this has implications for the types of learning that can take place.

Gilles Deleuze (1980) understood learning as part of the relationship between signs, events and bodies. Through this encounter with signs, thought discovers a problematic field of differential relations and singular points, which has internal and external relations. Thus, it is important to highlight the role of the medium (media) or the environment where learning has taken place. Instead of constructing a way of thinking that operates in the relationship between interiority and exteriority, between body and environment, or between mind and world, the most powerful thing to think about is the encounter between these beings, these corporealities and the signs they emit.

This entails a rejection of a representationalist understanding of the mind/world relationship (cf. MacLure, 2013), and its replacement with a notion of affect and sensation. An example of this is the image of swimming or of the swimmer, as a trace element for thinking about the aesthetic aspects of learning. With this image, we can think about learning as an event. The images in between are considered as surfaces of contrast through the internal and external dimensions and boundaries of world and mind. However, these relations are not produced by the distributions of a field. The image of swimming or of the swimmer is composed of powers to produce relations, and it is the task of thinking as learning to intuit the powers that compose these relations: learning to swim and learning to become a swimmer.
For Deleuze (1993) there is no 'representable concept' of swimming, at least not one from which anything new could be learned. There is only a dynamic event in which the distinctive points of a body combine with those of a wave. Swimming is thus not a static notion transmitted by a generic instructor to a generic student, but a dynamic form of becoming, modulated across the body of the teacher through the body of the student. 'The essence of swimming is never a stable, representable solution to the problem of what to do in the water. Rather, swimming poses a problem or introduces a problematic field in which we can learn: Where can I swim? When can I swim? How long and how fast can I swim? Will I swim or sink?' (Semetsky \& Delpech-Ramey, 2012, p. 74).

The image of swimming or of the swimmer is one of most powerful used by scholars who have studied relationships between education and Deleuzean philosophy. We will analyse images from two different experimental films, and this will allow us to reconstruct, replace and reposition the (human) subject at the centre of learning. Ronald Bogue (2008, p. 11) suggests that 'to learn is to immerse oneself within an alien element and thereby open oneself to an encounter with signs'. This reminds one of Gilles Deleuze's analysis of Marcel's taste of the madeleine (in Marcel Proust's À la recherche du temps perdu), which Bogue (ibid.) suggests is an analogy for the neophyte swimmer's initial dive into the sea: "signs 'cause' problems through their disorienting shock, forcing thought to deal with experiences that disrupt the common, coordinated functioning of the senses and faculties (Marcel's strange gustatory sensations resembling the swimmer's initial unorganized tactile micro-perceptions)".

Learning is taken to be neither a single homogeneous phenomenon, nor explained through single or simple causal relations. It is understood here as an aesthetic encounter with the world. Texts, for example, have the power to provoke new relations; bodies, not just human bodies, have powers to provoke images, depending on each new connection and relation, but the body is not reducible to the ideas or images we have of it.

We have chosen two different movies to extend the plane of thought about learning, in a context of heterogeneity, multiplicity and a-signifying ruptures, which are some of the rhizome's principles. These experimental movies are constructed as non-linear narratives and, as a result of their assemblage of sounds, colours and movements, open up the sense of experience of cinema-time. We will use these movies to highlight our critique of representation as the dominant image of the relationship between mind and reality (cf. MacLure, 2013). 
The two movies have been chosen because they have the capacity to disrupt the re-representation of swimming and the swimmer centered on human learning. Learning is taken to be neither a single homogeneous phenomenon, nor explained through single or simple causal relations. It is understood here as an aesthetic encounter with the world and as a singularity that expresses an idea of repetition; the return of difference from the virtual past. Texts, for example, have the power to provoke new relations; bodies, not just human bodies, have powers to provoke images, depending on each new connection and relation, but the body is not reducible to the ideas or images we have of it. What we are suggesting here is an idea of learning as an assemblage, incorporating hydraulics, turbulences, space/time folds, speeds, intensities, durations, lines, interstices of the cinema medium, expressions of the senses by images and sounds and the film montage, as well as, all of them operating rhizomatically (cf. Masny, 2013, 2016).

\section{The Movies}

Swimmer, directed by Michael Mazière, is a British production from 1987. It is seven minutes long with a beautiful photographic quality: https://www.youtube.com/watch?v=yeqpjZnynoo

Mazière's Swimmer uses freeze frame and repeat shots of a swimmer in what could only be the Mediterranean Sea. With a fractured soundtrack, what is lacking in depth (and this may be due to its serial nature) is made up by its surface tension. This is an aleatory composition of narrations, of forms and of emotions, which expresses the 'writing of movement, the writing of light, the alliance of an intelligence that decides and a machine that, because it wants nothing, recreates the very texture of the sensible universe, etc.' (Rancière, 2013, p. 191).

As Raymond Bellour (1997) suggests, the mixes, the relays, the passages of movements between images, take shape in two ways; on the one hand, an oscillation between the mobility and immobility of the image; on the other, between maintaining a photographic analogy and a tendency toward disfiguration. There is a sense in which 'we are now beyond the image' (ibid.), a sense in which it is now more productive to think in terms of a hybridity of the image. The essence of swimming is realised through the images that emerge in a plane of light, colours and sounds. These images of the experience of swimming are constructed by the movement of the camera; a tension captured from a time outside ordinary coordinates of temporal succession (derived from editing, modulating, framing and montage). It is similar to the "great joy that fills Marcel [Proust], which comes from this sudden encounter with what Proust calls 'a fragment of time in the pure state'" (Bogue, 2008, p. 4). It is the hybridity of images that embodies a taste of swimming and the learning experience of the swimmer. Here we have a virtual Mediterranean sea or a virtual swimmer in a body of affects. This is an unfolding difference.

The images in Swimmer do not discover any truth or learn anything other than processes of deciphering or interpretation. However, what emerges is a plurality of worlds where the images live in the film; its signs do not appear in the same way, they are not left to be deciphered in the same way and have no relation to an identical meaning. These are signs that form both the unity and its plurality. 
The second film is Lethe (2005), directed by Yuki Kawamura:

https://www.youtube.com/watch?v=nTnEsNL7Y48

It lasts for four minutes. Yuki Kawamura is a video-artist strongly influenced by his own Japanese culture. His work is characterised by a purist and minimalist approach that nevertheless comes across as both poetic and dreamlike. Fragile and luminous images are interwoven in the search for memory and an eternal unfading beauty. Two lovers swim in the river Lethe, the river of forgetfulness and oblivion. In Greek mythology, the river Lethe flowed through the Underworld, where all those who drank from it experienced complete amnesia. The lovers never meet and thus drift apart. A girl dives into the river to forget an unhappy love. At the centre of this film, a young woman wades into a river to forget an unhappy relationship. We initially see her on the banks of the river throwing a small stone into the water. These shots are followed by further underwater sequences in which coloured clothes are slowly propelled by the currents of the river. The sound of dreamy piano playing, together with the slowly superimposed images, lends the film a flowing and calming character. Suddenly, sections of bodies belonging to the unhappy lovers come into view amid the array of clothes. But as both lovers are moving in different directions, they never actually meet.

The underwater sequences, filmed during both the day and the night, make Lethe a bold aesthetic experiment, with colour, form and movement prioritised. Melancholy can be read into it both at concrete and metaphorical levels: as a consequence of unrequited love, but also as an irreplaceable loss of an exquisite aesthetic experience, duly encapsulated by Lethe's ephemeral, cinematic images. The river Lethe and Greek mythology allows us to construct relationships between the different images of the swimmer. The images in Lethe, from a Deleuzian perspective, lead to a shift in the logic of representation. The images of Lethe assume an identity of living beings; they are a result of operations of the sensible that are performed within visual art; however, living this eternity that identifies the living being is always differentiating.

Rather than insisting on the relationship between knowledge and subjects in order to re-think learning, this kind of questioning seeks to understand the interval between the encounter and what can be said about it: "sections of bodies belonging to the unhappy lovers come into view amid the various cloths. But as both lovers are moving in different directions, they never actually meet" (attached plot summary). This is learning about melancholy; learning with the signs. Through this encounter with signs, Ronald Bogue (2008, p. 57) suggests that "thought discovers a problematic field of differential relations and singular points that exists both within and without". He compares the reminiscence field of Marcel-madeleine-virtual Combray with the fluid sensorium-motor field of the swimmer-sea. The argument that is being made here is that it is necessary to use a kind of thinking that is without a subject and that can produce another image of thought.

It also happens in Lethe. Though it is within the actual that thought participates in the dynamic unfolding of the differential relations and singular point of the virtual domain, that virtual domain remains a-personal and pre-individual. For example, the flowers dancing into the clothes due to the water movement, or the images that show only parts of the swimmer's body pretend to connect us as spectators with the melancholy of the (non-) encounter of lovers. That bonding, in the case of Lethe, is built by 
desire. Desire is positive, striving to become what it is, but it is also different from all those desires with which it interacts.

From these interpretations of these two films, we can progress to the Deleuzian turn to the object of learning, understood as "the appropriate name for the subjective acts carried out when one is confronted with the objectivity of a problem (Idea), whereas knowledge designates only the generality of concepts or the calm of possession of a rule enabling solution" (Deleuze, 1968, p. 164). Deleuze resists the idea of a ground of being and truth existing behind appearance and difference and sets himself against an enlightenment injunction to turn back to the transcendental and universal ground from which a representation can emerge. The images of both experimental films are entities, which because of their dissonant connections may cause important semantic ruptures, and hermeneutic difficulties.

What this points to is a mediating process in the act of learning. The active and reactive force in learning is found in pre-defined places. Instead of thinking of a centered and conscious subject, we should be thinking of an agent or a result of heterogeneous and multiple assemblages. Reading a data assemblage is untimely and not pre-given. In the process, representation and interpretation are deterritorialised (virtual becoming) and re-territorialised (actualised) as sense and palpation in a post-qualitative research assemblage (cf. Masny, 2016). Both forces emanating from this subject as well as from the learning environment are active and reactive. In the encounter between bodies - swimmer and water - there is the elaboration of a force field that acts and reacts to the signs emitted by both bodies; then, both swimmer and the water, violently, are re-modelled. They never adjust or adapt themselves in harmony with each another. What is learnt is to enter into a kind of attunement that recognizes, responds, acts and reacts to the movements and pulses of the bodies in that encounter.

Expressing a feeling in action, for example, makes a difference to what that feeling is like. The minded action, as we suggested above, is not a representation of an action in the world, but an expression made manifest in an embodiment (cf. Taylor, 1985). We can make a similar association here with the idea of an expression, treating it as a form of human activity; meanings do not come before the expression, it is the expression itself that constitutes the meaning. It is a more powerful idea if connected to the characteristics of assemblages (cf. Buchanan, 2017).

With assemblages, the concept of the sign is crucial; because it is from the (non-) correspondence between the sign and what it means that "active" learning happens, since the violence of a-signification crosses both bodies (subject and environment), changing the ways we can perceive them. The performative characteristics of learning images of swimming and the swimmer as well as their use in the films, if looked at as assemblages, include humans and their social, legal, linguistic constructions; they also include some very active and powerful non-human constructions (cf. Bennett, 2010). The images, then, are non-human entities. They are individuated as singularities into the films. The cinema technologies produce "data", a corpus of sensations that reconfigure the subjects from their organic corporality: as light, colours, fragments, shadows, waves of water, interstices of time.

The water is the medium that provides the plasticity to compose the images of swimming and the swimmer. Deleuze insists that relations are always external or at least have an external dimension; what something is, the power it has to differ, produces a specific relation from itself, and this 
relation will differ according to its connections and encounters. If we take thought as a mode of desire this has two consequences: first, thought is construed differently according to the problem it addresses, and second, true thinking moves beyond established relations and approaches.

\section{Concluding Thoughts}

In this article, we have used the idea of the 'rhizome' to describe affective change. We have suggested through the images and sounds of the language of cinema, and in accordance with Felicity J. Colman (2010), that every operation in the world is the affective exchange of rhizomatically-produced intensities that create bodies, systems, economies, machines and thoughts.

The argument we have made here rests on four axioms: empirical research by necessity has an element of conceptual investigation; an example of an important concept in the world, indeed one we use all the time in our empirical and theoretical investigations, is learning; this involves an exploration of the relationship between mind and world; and this exploration of the relationship, we have suggested, is rhizomatic. We have addressed some of the issues that arise within each of these axioms, and perhaps more importantly, some of the relations between them. This has not been an easy task but since the world itself is complicated we should be careful not adopt reductionist and poorly theorised approaches to research and judgement, and consequently to the world. It is incumbent upon us, as part of a community of empirical social researchers in the world, not to take for granted and thus marginalise the reconceptualising modus operandi that is an essential part of the qualitative research process.

\section{Acknowledgment}

Fundação de Amparo à Pesquisa do Estado de São Paulo, FAPESP [São Paulo Research Foundation - 2015/25656-1]

\section{About the authors}

Antonio Carlos Rodrigues de Amorim is Professor of Curriculum, Language and Arts at School of Education at University of Campinas, São Paulo, Brazil. His four recent publications are: (with Marcus Novaes) Intensive Spatium and the Construction of Child Subjectivities in Brazilian Cinema, a chapter of the book Space and Subjectivity in Contemporary Brazilian Cinema, Palgrave Macmillan, 2017; (with David Martin-Jones) Powers of the False, Identity, and Identification in Contemporary Brazilian Comedies: Contributions to Curriculum Studies?, a paper published in AERA Online Paper Repository, San Antonio, 2017; the paper Audiovisual Compositions and Curriculum: Lines of Freedom,Didasc@alia: Didactica y Educación, 7 (3), 55-68, 2016; and Curriculum Disfiguration, a chapter in William Pinar's edited book Curriculum Studies in Brazil. Intellectual Histories, Present Circumstances, 55-70, New York, Brasil, Palgrave Macmillan, 2011.

David Scott is Emeritus Professor of Curriculum, Pedagogy and Assessment at the Institute of Education, University College London. His most recent books are: Equalities and Inequalities in the English Education System, London: University College London Institute of Education Press; and Education Systems and Learners: Knowledge and Knowers, London: Macmillan Palgrave. 


\section{References}

Baugh, B. (2010). Experimentation. En A. Parr (eds.). The Deleuze Dictionary, 93-95. Edinburgh: Edinburgh University Press.

Bellour, R. \& Hardyck, A. (2012). Raymond Bellour: between-the-Images. Zurich: JRP/Ringier.

Bennett, J. (2010). Vibrant Matter: A Political Ecology of Things. Duke and London: Duke University Press.

Bhaskar, R. (1998). General Introduction. In M. Archer, R. Bhaskar, A. Collier, T. Lawson \& A. Norrie (eds.). Critical Realism: Essential Readings, ix-xxiv, London: Routledge.

Bogue, R. (2008). Search, Swim and See. In I. Semetsky (ed.). Nomadic Education - Variations on a Theme by Deleuze and Guattari, 1-16. Rotterdam: Sense Publishers.

Brandom, R. (1994). Making it Explicit: Reasoning, Representing, and Discursive Commitment. Cambridge, Massachusetts: Harvard University Press.

Brandom, R. (2000). Articulating Reasons: An Introduction to Inferentialism. Cambridge, Massachusetts: Harvard University Press.

Brandom, R. (2004). The Pragmatist Enlightenment (and its Problematic Semantics), European Journal of Philosophy 12(1), 1-16. https://doi. org/10.1111/j.0966-8373.2004.00196.x

Buchanan, I. M. (2017). Assemblage Theory, or, the Future of an Illusion. Deleuze Studies, 11 (3), 457-474. http://dx.doi.org/10.3366/ dls.2017.0276

Colman, F. J. (2010). Rhizome. In A. Parr (eds.). The Deleuze Dictionary, 232-235. Edinburgh: Edinburgh University Press.

Deleuze, G. (1968). Différence et repetition (Paris, Presses Universitaires de France, PUF). Difference and Repetition. Paul Patton (transl.). New York: Columbia University Press.

Deleuze, G. (1993). The Fold: Leibniz and the Baroque. Tom Conley (trans.). Minneapolis: University of Minnesota Press.

Deleuze, G. (2006). Nietzsche and Philosophy. Michael Hardt (trans.). New York: Columbia University Press, European Perspectives Series.

Deleuze, G. \& Guattari, F. (1980). Mille Plateaux. (Paris: Minuit). A Thousand Plateaus, by Brian Massumi (trans.). Minneapolis: University of Minnesota Press.

Fodor, J. \& Lepore, E. (2007). Brandom Beleaguered. Philosophy and Phenomenological Research, 74 (3), 677-691. https://doi.org/10.1111/ j.1933-1592.2007.00045.x

Kawamura, Y. (2005). Lethe. Available at: https://www.youtube.com/ watch? $v=n T n E s N L 7 Y 48$

Lambert, G. (2012). In Search of a New Image of Thought: Gilles Deleuze and Philosophical Expressionism. Minneapolis: University of Minnesota Press.

MacLure, M. (2013). Researching without Representation? Language and Materiality in Post-Qualitative Methodology. International Journal of Qualitative Studies in Education, 26 (6), 658-667. https://doi.org/10.1 080/09518398.2013.788755

Masny, D. (2013). Rhizoanalytic Pathways in Qualitative Research: Problematizing the Qualitative. Qualitative Inquiry, 19 (5), 339-348. https://doi.org/10.1177/1077800413479559

Masny, D. (2016). Problematizing Qualitative Research: Reading a Data Assemblage With Rhizoanalysis. Qualitative Inquiry, 22 (8), 666675. https://doi.org/10.1177/1532708616636744 
Mazière, M. (1987). Swimmer. United Kingdom, France. Available at: https://www.youtube.com/watch?v=yeqpjZnynoo

Rancière, J. (2013). Remarks by Way of a Postface. In P. Bowman (ed.). Rancière and Film, 185-193. Edinburgh: Edinburgh University Press.

Scott, D. (2011). Education, Epistemology and Critical Realism. London, New York: Routledge.

Sellars, W. (1997). Empiricism and the Philosophy of Mind. Cambridge, Massachusetts: Harvard University Press.

Semetsky, I. \& Delpech-Ramey, J. A. (2012). Jung's Psychology and Deleuze's Philosophy: The Unconscious in Learning. Educational Philosophy and Theory, 44 (1), 69-81. https://doi.org/10.1111/j.14695812.2010.00670.x

Standish, P. (2016). The Disenchantment of Education and the Re-enchantment of the World. Journal of Philosophy of Education, 50 (1), 98116. https://doi.org/10.1111/1467-9752.12176

Taylor, C. (1985). Human Agency and Language: Philosophical Papers 1, Chapter 1: What is Human Agency? and Chapter 3: Hegel's Philosophy of Mind. Cambridge: Cambridge University Press.

Taylor, C. (2011). Dilemmas and Connections. Harvard, Massachusetts: Harvard University Press. 